\title{
PENGARUH PARTISIPASI PENYUSUNAN ANGGARAN, MOTIVASI, JOB RELEVANT INFORMATION, KEBIJAKAN PENYUSUNAN ANGGARAN DAN PELIMPAHAN WEWENANG TERHADAP KINERJA MANAJERIAL SKPD KABUPATEN KEPULAUAN TALAUD
}

\author{
Aljeni Murahati Rellam, Grace B. Nangoi, Jenny Morasa \\ (Email : rellamjeni@gmail.com)
}

\begin{abstract}
This study aims to determine the effect of budget participation to managerial performance SKPD Talaud Islands, to determine the effect of motivation budgeting on managerial performance SKPD Talaud Islands, To know the job relevant information budgetary against Managerial Performance SKPD Talaud Islands, to know the Policy Formulation budget of the Managerial performance Talaud Islands, to determine the influence of delegation of authority budgeting on Managerial performance SKPD Talaud Islands, to determine jointly the effect of budget participation, motivation budgeting, job relevant information budgeting, policy budgeting, delegation of authority budgeting on managerial performance SKPD Talaud Islands. The population in this study was 105 respondents from 35 SKPD in Government Talaud Islands. Samples were selected using purposive sampling method, as many as 105 employees / officers who have served as Secretary, Head of Finance and Head of Planning / Program for primary data tested were from 105 respondents are already established. The analytical method used is multiple linear regression analysis and before the data is processed first tested using the classical assumption test. As for the process of research data using SPSS version 15.0. The results showed evidence that budget participation, motivation budgeting, job relevant information budgeting, no significant effect on managerial performance. And research shows evidence that the policy of budgeting, delegation of authority budgeting significant effect on managerial performance.
\end{abstract}

Keywords: Participation budgeting, motivation budgeting, job relevant information budgeting, budgeting policies, delegation of authority budgeting on managerial performance

\section{PENDAHULUAN}

Indonesia menerapkan suatu azas desentralisasi dalam pelaksanaan pemerintahan di berbagai daerah, dengan maksud untuk memberikan suatu kebebasan dan keleluasaan kepada Pemerintah Daerah dalam menyelenggarakan pemerintahan melalui Otonomi Daerah.Otonomi dan desentralisasi fiscal di Indonesia diatur dalam beberapa aturan. Pemerintah Daerah diharapkan untuk lebih memperhatikan serta memberikan pelayanan kepada masyarakat dengan segala kondisi untuk mensejaterahkan rakyat dengan menerapkan asas-asas pelayanan publik yang didalamnya meliputi; (1) transparansi; (2) akuntabilitas; (3) partisipatif; (4) kesamaan hak; (5) keseimbangan hak; (6) dan kewajiban. Untuk maksud tersebut diatas perlu adanya perencanaan.

Berdasarkan uraian diatas peneliti tertarik melakukan penelitian dengan judul Pengaruh Partisipasi Penyusunan Anggaran, Motivasi Penyusunan Anggaran, Job Relevant Information Penyusunan Anggaran, Kebijakan Penyusunan Anggaran dan Pelimpahan Wewenang Penyusunan Anggaran terhadap Kinerja Manajerial SKPD karena diangkatnya Kinerja Manajerial sebagai faktor kunci yang diteliti. Kinerja Manajerial sangat berpengaruh terhadap kinerja seorang pimpinan atau kinerja pemerintah daerah ditentukan oleh kinerja aparat yang ada di SKPD pada pemerintah daerah tersebut. Kinerja aparat pada SKPD Kabupaten Kepulauan Talaud masih menimbulkan pertentangan (Kontradiktif) antara kedekatan pimpinan daerah dengan aparat yang ada di SKPD, Seorang aparat yang 
mempunyai hubungan secara khusus dengan pimpinan daerah akan diperlakukan secara khusus pula oleh pimpinan daerah, hal ini dapat dilihat dalam penentuan aparat pada jabatan dengan tidak memperhatikan kinerja maupun tingkat kompetensi yang sesungguhnya (Waney 2012:8), yang artinya Kinerja aparatur pemerintah tidak diukur dengan kemampuan melakukan suatu pekerjaan (kompetensi) atau sesuai dengan tingkat pendidikan tetapi diukur kedekatan dengan pimpinan yang lebih tinggi. Dalam penelitian ini terdapat penyusunan anggaran di Daerah Kabupaten Kepulauan Talaud sebagian besar masih ketergantungan pada keputusan top manajemen, kurangnya pelimpahan wewenang kepada middle manajemen yang secara langsung berhubungan dengan teknik lapangan, Sehingga perlu adanya keterlibatan dari middle manajemen dalam perencanaan penyusunan anggaran, Pemilihan SKPD yang ada di Kabupaten Kepulauan Talaud, karena masih banyak permasalahan yang perlu dibenahi yang terjadi, untuk bisa mendapat opini yang lebih baik lagi di masa yang akan datang.

Berdasarkan latar belakang dan rumusan masalah yang telah diuraikan, maka akan diperjelas objek yang diteliti dengan pertanyaan sebagai berikut.

1. Apakah partisipasi penyusunan anggaran berpengaruh terhadap kinerja manajerial SKPD Kabupaten Kepulauan Talaud?

2. Apakah motivasi penyusunan anggaran berpengaruh terhadap kinerja manajerial SKPD Kabupaten Kepulauan Talaud?

3. Apakah job relevant information penyusunan anggaran berpengaruh terhadap kinerja manajerial SKPD Kabupaten Kepulauan Talaud?

4. Apakah kebijakan penyusunan anggaran berpengaruh terhadap kinerja manajerial SKPD Kabupaten Kepulauan Talaud?

5. Apakah pelimpahan wewenang penyusunan anggaran berpengaruh terhadap kinerja manajerial SKPD Kabupaten Kepulauan Talaud?

Tujuan penelitian ini sebagai berikut:

1. Menganalisis pengaruh partisipasi penyusunan anggaranterhadap kinerja manajerial pemerintah di SKPD.

2. Menganalisis pengaruh motivasipenyusunan anggaran terhadap kinerja manajerial pemerintah di SKPD.

3. Menganalisis pengaruh job relevant information penyusunan anggaran terhadap kinerja manajerial pemerintah di SKPD.

4. Menganalisis pengaruh kebijakan penyusunan anggaran terhadap kinerja manajerial pemerintah di SKPD.

5. Menganalisis pengaruh pelimpahan wewenang penyusunan anggaran, terhadap kinerja manajerial di SKPD.

\section{TINJAUAN PUSTAKA}

\section{Teori keagenan (Agency Theory)}

Agensi teori mengakibatkan hubungan yang asimetri antara masyarakat dan pemerintah, untuk menghindariterjadi hubungan yang asimetri tersebut dibutuhkan suatu konsep yaitu konsep Good Corporate Governance yang bertujuan untuk menjadikan perusahaanmenjadi lebih sehat.Penerapan corporate governance berdasarkan pada teoriagensi, yaitu teori agensi dapat dijelaskan dengan hubungan antara manajemendengan pemilik, manajemen sebagai agen yaitu pemerintah secara moral bertanggung jawabuntuk mengoptimalkan keuntungan para pemilik (principal) yaitu masyarakat dan sebagaiimbalannya akan memperoleh kompensasi yang sesuai dengan perjanjian kerja(kontrak).Mekanisme corporate governance memiliki kemampuan pengendalian yang dapat mensejajarkan perbedaan kepentingan antara principal (masyarakat) dan agen 
(pemerintah), sehingga dapat menghasilkan suatu laporan keuangan yang memiliki kandungan informasi laba yang berkualitas (Boediono, 2005:176).

\section{Partisipasi Penyusunan Anggaran}

Banyak ahli memberikan pengertian mengenai konsep partisipasi. Bila dilihat dari asal katanya, kata partisipasi berasal dari kata bahasa Inggris "participation"yang berarti pengambilan bagian, pengikutsertaan (Echols John M \& Hasan Shadily 2000:419). Partisipasi berarti peran serta seseorang atau kelompok masyarakat dalam proses pembangunan baik dalam bentuk pernyataan maupun dalam bentuk kegiatan dengan memberi masukan pikiran, tenaga, waktu, keahlian, modal dan atau materi, serta ikut memanfaatkan dan menikmati hasil-hasil pembangunan (I Nyoman Sumaryadi, 2010: 46).

\section{Teori Motivasi.}

Teori hierarki kebutuhan Maslow adalah teori yang diungkapkan oleh Abraham Maslow.Ia beranggapan bahwa kebutuhan-kebutuhan di tingkat rendah harus terpenuhi atau paling tidak cukup terpenuhi terlebih dahulu sebelum kebutuhan-kebutuhan di tingkat lebih tinggi menjadi hal memotivasi. Berdasarkan pengamatan Maslow, didapatkan kesimpulan bahwa beberapa kebutuhan lebih diutamakan dibandingkan dengan kebutuhan yang lain.Maslow juga menambahkan bahwa, pemuasan berbagai kebutuhan tersebut didorong oleh dua kekuatan yakni motivasi kekurangan (deficiency motivation) dan motivasi perkembangan (growth motivation).Motivasi kekurangan bertujuan untuk mengatasi masalah ketegangan manusia karena berbagai kekurangan yang ada.

\section{Job Relevant Information penyusunan anggaran}

Omposunggu dan Bawono (2006) mengidentifikasi 2 jenis informasi utama dalam organisasi yaitu decision influencing dan Job-Relevant Information (JRI).Decision influencing adalah informasi yang dikumpulkan tentang sikap manajer untuk mengevaluasi kinerja.Sedangkan Job-Relevant Information(JRI) adalah informasi internal organisasi yang cenderung berhubungan dengan tugas yang dihasilkan oleh karyawan.Informasi-informasi tersebut dapat memberikan prediksi lingkungan dengan lebih tepat dan memungkinkan pilihan suatu kebijakan yang lebih baik sehingga memperbaiki kinerja.

\section{Kebijakan Penyusunan Anggaran}

Definisi kebijakan adalah rangkaian konsep dan asas yang menjadi pedoman dan dasar rencana dalam pelaksanaan suatu pekerjaan kepemimpinan dan cara bertindak. Definisi Kebijakan juga diungkapkan lagi oleh Nugroho, menurut Nugroho (2004) kebijakan adalah sebagai segala sesuatu yang dikerjakan dan yang tidak dikerjakan oleh pemerintah sebagai tokoh sentral publik. Dengan demikian suatu kebijakan erat kaitannya dengan berbagai produk kebijakan yang dikeluarkan oleh lembaga pemerintahan (organisasi sektor publik).

Dalam penelitian ini, Variabel yang diambil dalam kebijakan penyusunan anggaran adalah kemampuan seorang manajer atau aparat pemerintahan mengenai pengelolaan anggaran pada Satuan Kerja PerangkatDaerah (SKPD) Kabupaten Kepulauan Talaud sebagai variabel independen, dimana variabel tersebut berpengaruh signifikan terhadap penyusunan anggaran untuk pelaksanaan program kegiatan yang ada di SKPD, dengan indikator yang di gunakan untuk mengukur variable ini adalah, pencapaian realisasi pelaksanaan kegiatan, seberapa banyak program kegiatan yang dilaksanakan sesuai dengan anggaran yang tersedia dan apa dampak dari hasil kegiatan yang dilaksanakan terhadap pegawai dengan kebijakan yang diambil.

\section{Pelimpahan Wewenang Penyusunan Anggaran}

Menurut Lubis secara Etimologis, istilah Kewenangan berasal dari kata Wewenang.Sedangkan menurut Bagir Manan, istilah Wewenang dengan kekuasaan itu berbeda.Kekuasaan menurutnya hanya digambarkan hak untuk berbuat, sedangkan Wewenang memiliki pengertian yang lebih luas meliputi hak dan kewajiban. Secara teoritik, mengenai kewenangan dapat dilihat pendapat Stout yang dikutip oleh Ridwan (2006) 
mengatakan: "Wewenang merupakan pengertian yang berasal dari Hukum Organisasi Pemerintahan, yang dapat dijelaskan sebagai keseluruhan aturan-aturan yang berkenaan dengan perolehan dan penggunaan Wewenang Pemerintahan oleh subjek Hukum publik didalam hubungan Hukum publik. Pandangan yang melihat lebih jauh pada sisi tindakan, yaitu ungkapan Nicolai dalam Ridwan (2006:102) Kemampuan untuk melakukan tindakan hukum tertentu (yaitu tindakan-tindakan yang dilakukan untuk mengakibatkan tindakan Hukum, dan mencakup mengenai timbul dan lenyapnya akibat Hukum).

\section{Kinerja Manajerial}

Penelitian Anwar (2010) menyatakan bahwa kinerja manajerial merupakan proses perencanaan, pengorganisasian, pelaksanaan, dan pengendalian terhadap pencapaian kinerja dan dikomunikasikan secara terus menerus oleh pimpinan kepada karyawan, antara karyawan dengan atasannya langsung. Menurut Mulyadi (2001) dikutip oleh Albertus dan Ardianu (2010) Penilaian Kinerja adalah Penentu secara Periodik efektivitas suatu Organisasi, bagian Organisasi dan karyawannya berdasarkan sasaran standard dan kriteria yang telah ditetapkan sebelumnya. Penelitian ini mendefinisikan kinerja manajerial sebagai kinerja anggota individu untuk pencapaian tujuan banyak orang lewat sumbangan tenaga fikiran dan waktu tanpa pamrih.

\section{KERANGKA KONSEPTUAL}

Hubungan tidak langsung antara partisipasi penyusunan anggaran, motivasi penyusunan anggaran, job relevant information penyusunan anggaran, kebijakan penyusunan anggaran dan pelimpahan wewenang penyusunan anggaran terhadap kinerja manajerial dimediasi oleh komitmen organisasi dan persepsi inovasi sebagai variabel intervening. Variabel-variabel ini yang kemungkinan akan mempengaruhi Kinerja Manajerial aparatur Pemerintah daerah dalam pelaksanaan tugas di SKPD masing-masing.Berdasarkan latar belakang, tinjauan pustaka dengan teori-teori yang telah dijelaskan, maka kerangka konseptual dari penelitian ini dapat dilihat pada gambar 3.1.

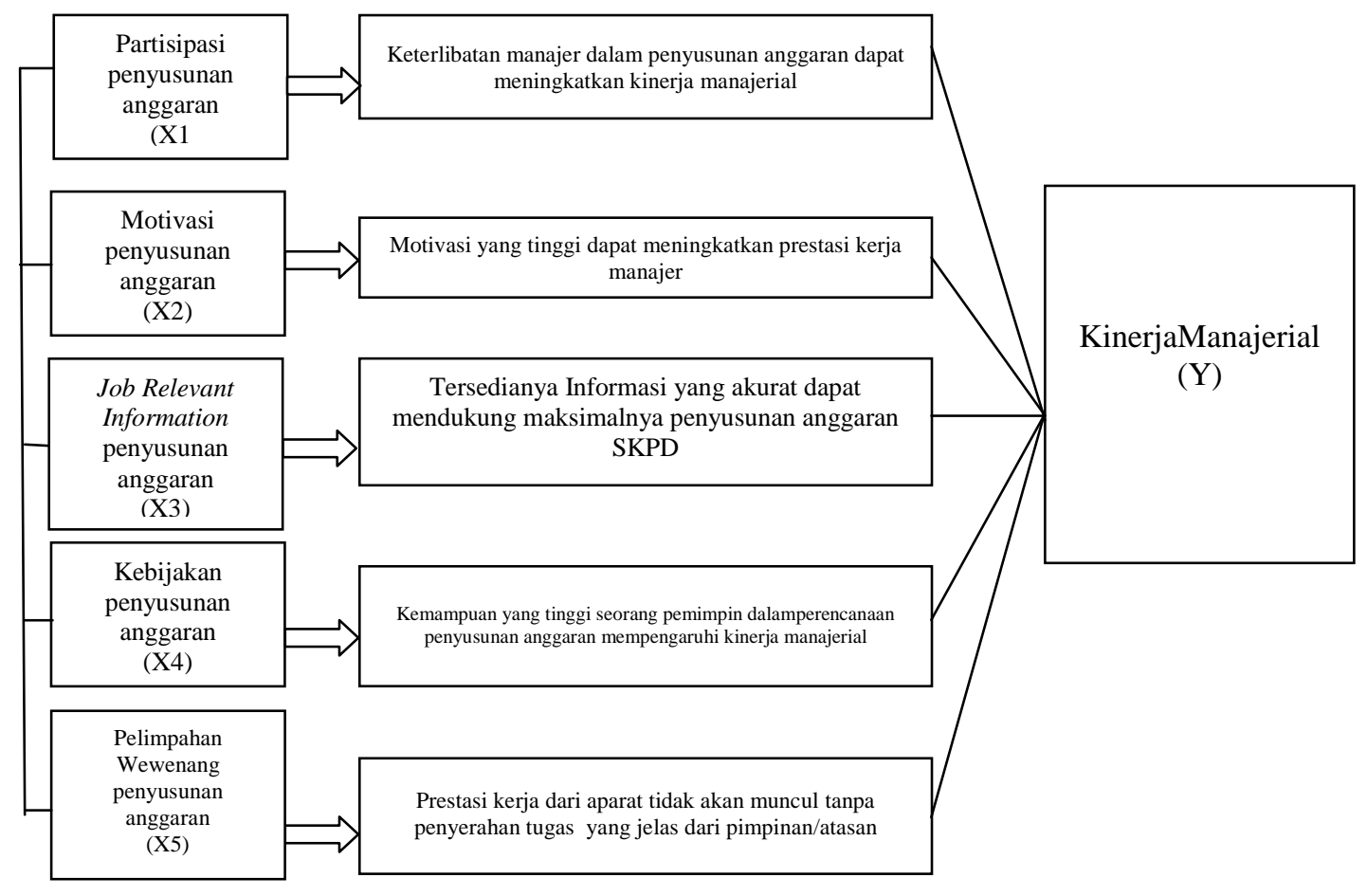

Gambar 3.1 Kerangka Konseptual Penelitian 


\section{Hipotesis Penelitian}

Berdasarkan permasalahan yang telah dikemukakan sebelumnya dan kerangkakonseptual tersebut diatas, maka dapat dirumuskan hipotesis sebagai berikut.

Ha1 : Partisipasi penyusunan anggaran berpengaruh positif terhadap kinerja manajerial SKPD Daerah di Kabupaten Kepulauan Talaud.

Ha2 : Motivasi penyusunan anggaran berpengaruh positif terhadap kinerja Manajerial SKPD Daerah di Kabupaten Kepulauan Talaud

Ha3 : Job Relevant Information Penyusunan Anggaran berpengaruh Positif Terhadap Kinerja Manajerial SKPD Daerah Kabupaten Kepulauan Talaud

Ha4 : Kebijakan Penyusunan Aggaran berpengaruh positif terhadap Kinerja Manajerial SKPD Daerah Kabupaten Kepulauan Talaud

Ha5 : Pelimpahan Wewenang penyusunan anggaran berpengaruh positif terhadap Kinerja Manajerial SKPD Daerah di Kabupaten Kepulauan Talaud

\section{METODE PENELITIAN}

\section{Jenis Penelitian yang Digunakan}

Sumber data penelitian ini adalah data primer yang berasal dari jawaban responden atas beberapa pertanyaan yang diajukan peneliti melalui wawancara kuesioner dan data sekunder yang didapat secara langsung oleh peneliti dari literatur, studi pustaka, jurnal-jurnal penelitian terdahulu yang berhubungan dengan penelitian dalam penelitian ini.

\section{Populasi, Sampel, Besar Sampel, dan Teknik Pengambilan Sampel}

Populasi dalam penelitian ini adalah unsur pimpinan dan staf dinas/badan di Kabupaten Kepulauan Talaud. Populasi dalam penelitian ini adalah SKPD yang terdapat di Kabupaten KepulauanTalaudantara lain yaitu: (Sekretariat Daerah, DPPKAD, BAPEDA, Sekretariat Dewan,Dinas PU, Dinas Kesehatan, Badan, Kantor, Satuan dan kecamatan, dengan jumlah Populasi sebanyak 35 SKPD dan jumlah sampel sebanyak 105 responden.

\section{Klasifikasi Variabel dan Definisi Operasional Variabel}

1. Kinerja Manajerial (Y); adalah suatu cara kerja individu, anggota dalam suatu organisasi dalam melaksanakan suatu tugas dan tanggungjawab yang kegiatannya antara lain: perencanaan, investigasi, koordinasi, pengaturan staf, negosiasi dan lain-lain.

2. Partisipasi Penyusunan Anggaran ( $\left.\mathbf{X}_{1}\right)$;Adalah Suatu keterlibatan dari seseorang atau kelompok dalam melaksanakan suatu pekerjaan.

3. Motivasi penyusunan anggaran $\left(\mathbf{X}_{2}\right)$; adalahmerupakan derajat sampai dimana individu ingin dan berusaha untuk melaksanakan suatu pekerjaan dengan baik (Ghosali 2002).

4. Job Relevant Information penyusunan anggaran $\left(\mathbf{X}_{3}\right)$; adalahmerupakan kemampuan baik dalam tingkat induvidu, organisasi/ kelembagaan, maupun sistem untuk melaksanakan fungsi-fungsi atau kewenangannya untuk mencapai tujuannya secara efektif dan efisien.

5. Kebijakan Penyusunan Anggaran $\left(\mathbf{X}_{\mathbf{4}}\right)$; adalah sebagai sesuatu yang dikerjakan dan yang tidak dikerjakan oleh pemerintah sebagai tokoh sentral publik, Nugroho (2004)

6. Pelimpahan Wewenang penyusunan anggaran $\left(\mathbf{X}_{5}\right)$, adalah proses pengalihan tugas kepada orang lain yang sah atau terlegitimasi (menurut mekanisme tertentu dalam organisasi) dalam melakukan berbagai aktifitas yang ditujukan untuk pencapaian tujuan organisasi yang jika tidak dilimpahkan akan menghambat proses pencapaian tujuan tersebut. 


\section{ANALISIS DAN PEMBAHASAN HASIL PENELITIAN}

\section{Uji Asumsi Klasik}

Uji Normalitas, Uji normalitas dilakukan untuk mengetahui apakah data sampel memenuhi persyaratan distribusi normal. Persyaratan data disebut normal jika probabilitas atau $\mathrm{p}>0,05$ pada uji normalitas dengan kolmogorovsmirov. Pada Tabel 5.7 untuk variabel Kinerja Manajerial terdistribusi normal dengan nilai $\mathrm{p}=0,129>0,05$ maka data variabel Kinerja Manajerial pada 105 (Seratus Lima) sampel adalah normal atau memenuhi persyaratan uji normalitas.

Uji Multikolinearitas, digunakan untuk mengetahui apakah terjadi korelasi yang kuat di antara variabel-variabel independen yang diikutsertakan dalam pembentukan model.Dengan melihat Angka VIF pada table 5.22 semua variabel independen berada di bawah 5, yaitu partisipasi penyusunan anggaran (X1) sebesar 1,381, motivasi penyusunan anggaran (X2) sebesar 1,135, job relevant information penyusunan anggaran sebesar 1,329, kebijakan penyusunan anggaran (X4) sebesar 2,035, pelimpahan wewenang penyusunan anggaran (X5) sebesar 2,149, yang berarti antar variabel independen tidak terjadi efek multikolinearitas.

Uji heteroskedastisitas,menggunakan uji Glesjer.Suatu penelitian terjadi heteroskedastisitas dapat dilihat melalui tingkat signifikansi pada table 5.23 statistik heterokedastisitas apakah tingkat signifikansinya > 0,05. Berdasarkan table 5.23 dapat disimpulkan bahwa variable partisipasi penyusunan anggaran (X1), motivasi penyusunan anggaran (X2), job relevant information penyusunan anggaran (X3), kebijakan penyusunan anggaran (X4), pelimpahan wewenang penyusunan anggaran (X5), tingkat signifikansi variable independent terhadap residual error data berada diatas 0,05 , sehingga varians data penelitian tidak mengalami gejala heteroskedasitas.

\section{Uji Hipotesis}

Uji Model Fit (Uji F), Uji F dilakukan untuk mengetahui apakah variabel-variabel independen partisipasi penyusunan anggaran $\left(\mathrm{X}_{1}\right)$, motivasi penyusunan anggaran $\left(\mathrm{X}_{2}\right)$, job relevant information penyusunan anggaran $\left(\mathrm{X}_{3}\right)$, kebijakan penyusunan anggaran $\left(\mathrm{X}_{4}\right)$,pelimpahan wewenang penyusunan anggaran(X5) secara bersama-sama mempunyai pengaruh terhadap variabel dependen Kinerja Manajerial (Y). Dari hasil output uji koefisien regresi secara bersama-sama (Uji F) dapat diketahui nilai $\mathrm{F}$ pada Tabel 5.26.Berdasarkan

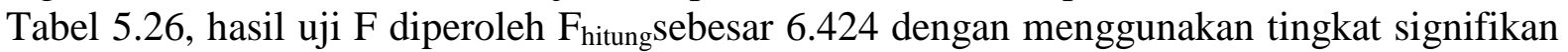
$\mathrm{P}=0.00<\alpha=0.05$ maka dapat disimpulkan bahwa variabel partisipasi penyusunan anggaran $\left(\mathrm{X}_{1}\right)$, motivasi penyusunan anggaran $\left(\mathrm{X}_{2}\right)$, job relevant information penyusunan anggaran $\left(\mathrm{X}_{3}\right)$, kebijakan penyusunan anggaran $\left(\mathrm{X}_{4}\right)$, pelimpahan wewenang penyusunan anggaran (X5) secara bersama-sama uji $\mathrm{F}$ menunjukan hasil signifikan yang berarti bahwa model penelitian adalah fit dan seluruh variable independen secara simultan adalah signifikan terhadap variable dependen.

Uji t, Penggunaan regresi linier berganda dalam uji t memberikan hasil yang bila dimasukkan ke dalam persamaan penelitian menjadi:maka persamaan regresi yang diperoleh adalah sebagai berikut: $Y=2,043-0,177 X 1-0,031 X 2+0,122 X 3+0,278 X 4+0,310 X 5$

Variabel $\mathrm{X}_{1}$ (partisipasi penyusunan anggaran) sebesar 0,177 , ini berarti bahwa jika partisipasi meningkat sebesar 1 satuan skor, maka akan mengalami penurunan nilai kinerja manajerial sebesar 0,177 satuan skor dari kondisi sebelumnya, dengan asumsi variable lainnya tetap. Hal ini berarti pula bahwa tidak terdapat hubungan yang positif antara partisipasi penyusunan anggaran dengan kinerja manajerial. Dengan kata lain adanya peningkatatan pada variable partisipasi penyusunan anggaran $\left(\mathrm{X}_{1}\right)$, akan menurunkan kinerja manajerial (Y) SKPD pada pemerintah kabupaten kepulauan Talaud.

Variabel $\mathrm{X}_{2}$ (motivasi penyusunan anggaran) sebesar 0,031, ini berarti bahwa jika motivasi meningkat sebesar 1 satuan skor, maka akan mengalami penurunan nilai kinerja 
manajerial sebesar 0,031 satuan skor, maka akan mengalami penurunan nilai kinerja manajerial sebesar 0,031 satuan skor dari kondisi sebelumnya, dengan asumsi variable lainnya tetap. Hal ini berarti pula bahwa tidak terdapat hubungan yang positif antara motivasi penyusunan anggaran dengan kinerja manajerial. Dengan kata lain adanya peningkatatan pada variable motivasi penyusunan anggaran $\left(\mathrm{X}_{2}\right)$, akan menurunkan kinerja manajerial $(\mathrm{Y})$ SKPD pada pemerintah kabupaten kepulauan Talaud.

Variabel $\mathrm{X}_{3}$ (job relevant information penyusunan anggaran) sebesar 0,112 , ini berarti bahwa jika job relevant information penyusunan anggaran meningkat sebesar 1 satuan skor, maka akan mengalami peningkatan nilai kinerja manajerial sebesar 0,112 satuan skor dari kondisi sebelumnya, dengan asumsi variable lainnya tetap.Hal ini berarti pula bahwa terdapat hubungan yang positif antara job relevant information penyusunan anggaran dengan kinerja manajerial. Dengan kata lain adanya peningkatan pada variable job relevant information penyusunan anggaran $\left(\mathrm{X}_{3}\right)$, akan meningkatkan kinerja manajerial (Y) SKPD pada pemerintah kabupaten kepulauan Talaud.

Variabel $\mathrm{X}_{4}$ (kebijakan penyusunan anggaran) sebesar 0,278, ini berarti bahwa jika kebijakan penyusunan anggaran meningkat sebesar 1 satuan skor, maka akan mengalami peningkatan nilai kinerja manajerial sebesar 0,278 satuan skor dari kondisi sebelumnya, dengan asumsi variable lainnya tetap. Hal ini berarti pula bahwa terdapat hubungan yang positif antara kebijakan penyusunan anggaran dengan kinerja manajerial. Dengan kata lain adanya peningkatan pada variable kebijakan penyusunan anggaran (X4), akan meningkatkan kinerja manajerial (Y) SKPD pada pemerintah kabupaten kepulauan Talaud.

Variabel $\mathrm{X}_{5}$ (pelimpahan wewenang penyusunan anggaran) sebesar 0,310, ini berarti bahwa jika pelimpahan wewenang penyusunan anggaran meningkat sebesar 1 satuan skor, maka akan mengalami peningkatan nilai kinerja manajerial sebesar 0,310 satuan skor dari kondisi sebelumnya, dengan asumsi variable lainnya tetap. Hal ini berarti pula bahwa terdapat hubungan yang positif antara pelimpahan wewenang dengan kinerja manajerial. Dengan kata lain adanya peningkatan pada variable pelimpahan wewenang penyusunan anggaran $\left(\mathrm{X}_{5}\right)$, akan meningkatkan kinerja manajerial (Y) SKPD pada pemerintah kabupaten kepulauan Talaud.

Koefisien Determinasi $\left(\mathbf{R}^{2}\right)$ dan Korelasi (r), nilai koefisien korelasi linier ® yang dihasilkan antara variable partisipasi penyusunan anggaran $\left(\mathrm{X}_{1}\right)$, motivasi penyusunan anggaran $\left(\mathrm{X}_{2}\right)$, job relevant information penyusunan anggaran $\left(\mathrm{X}_{3}\right)$, kebijakan penyusunan anggaran $\left(\mathrm{X}_{4}\right)$, pelimpahan wewenang penyusunan anggaran $\left(\mathrm{X}_{5}\right)$ dan variable kinerja manajerial (Y) sebesar 0,495. Nilai korelasi ${ }^{\circledR}$ sebesar 0,495 menunjukan adanya hubungan yang kuat antara variable $\mathrm{X}_{1}, \mathrm{X}_{2}, \mathrm{X}_{3}, \mathrm{X}_{4}, \mathrm{X}_{5}$ dengan variable $\mathrm{Y}$. Sedangkan nilai $\mathrm{R}$ Square atau koefisien determinasi $\left(\mathrm{R}^{2}\right)$ sebesar 0,245 menunjukan bahwa kontribusi variable $\mathrm{X}_{1}, \mathrm{X}_{2}, \mathrm{X}_{3}, \mathrm{X}_{4}, \mathrm{X}_{5}$ untuk menjelaskan model variable $\mathrm{Y}$ adalah sebesar $24,5 \%$ dan sisanya $75,5 \%$ dijelaskan oleh factor lain yang tidak dimasukan dalam penelitian ini.

\section{Pembahasan}

\section{Pengaruh Partisipasi penyusunan anggaran $\left(X_{1}\right)$ terhadap Kinerja Manajerial $(Y)$}

Variabel partisipasi penyusunan anggaran $\left(\mathrm{X}_{1}\right)$ mempunyai nilai $(-0,177)$ tidak berpengaruh signifikan terhadap Kinerja Manajerial.Dengan artian Jika partisipasi penyusunan anggaran naik maka kinerja manajerial turun (berbanding terbalik).Hal ini disebabkan karena tidak semua pegawai yang memiliki Partisipasi penyusunan anggaran yang tinggi paham dan bisa menyelesaikan permasalahan dalam Penyusunan anggaran.

\section{Pengaruh Motivasi penyusunan anggaran $\left(X_{2}\right)$ terhadap Kinerja Manajerial (Y)}

Hasil penelitian ini bahwa secara parsial variabel Motivasi penyusunan anggaran $\left(\mathrm{X}_{2}\right)$ mempunyai nilai $(-0,031)$ tidak berpengaruh signifikan terhadap Kinerja Manajerial. Dalam artian jika motivasi penyusunan anggaran naik maka kinerja manajerial akan turun (berbanding terbalik). 
3. Job Relevant Information penyusunan anggaran $\left(X_{3}\right)$ terhadap Kinerja $\operatorname{Manajerial}(\mathbf{Y})$

Hasil penelitian hipotesis ini menyatakan bahwa variabel Job Relevant Information penyusunan anggaran $\left(\mathrm{X}_{3}\right)$ mempunyai nilai $(0,112)$ tidak berpengaruh signifikan terhadap Kinerja Manajerial.

4. Pengaruh Kebijakan Penyusunan Anggaran $\left(\mathrm{X}_{4}\right)$ terhadap Kinerja Manajerial $(\mathrm{Y})$ Hasil pengujian hipotesis menunjukkan variabel Kebijakan Penyusunan Anggaran $\left(\mathrm{X}_{4}\right)$ mempunyai nilai $(0,278)$ berpengaruh signifikan terhadap Kinerja Manajerial.

5. Pengaruh Pelimpahan Wewenang penyusunan anggaran $\left(X_{5}\right)$ terhadap Kinerja Manajerial (Y)

Hasil pengujian hipotesis menunjukkan variabel Pelimpahan Wewenang Penyusunan Anggaran $\left(\mathrm{X}_{5}\right)$ dengan nilai $(0,310)$ berpengaruh terhadap Kinerja Manajerial.

\section{KESIMPULAN DAN SARAN}

\section{Kesimpulan}

1. Partisipasi penyusunan anggaran $\left(X_{1}\right)$ menunjukan secara parsial tidak berpengaruh terhadap Kinerja Manajerial SKPD Kabupaten Kepulauan Talaud, dalam artian bahwa tidak ada keterlibatan aparat SKPD level menengah dalam penyusunan anggaran SKPD. Dengan demikian penelitian ini tidak mendukung hipotesis 1. Yang berarti keterlibatan Sekretaris, Kasubag Keuangan, Kasubag Perencanaan/Program tidak mempengaruhi Kinerja Manajerial.

2. Hipotesis Motivasi penyusunan anggaran $\left(\mathrm{X}_{2}\right)$ secara parsial tidak berpengaruh terhadap Kinerja Manajerial SKPD pada Kabupaten Kepulauan Talaud, Hasil pengujian uji parsial atau uji t Motivasi tidak berpengaruh terhadap Kinerja manajerial SKPD pada Kabupaten Kepulauan Talaud. Yang berarti keterlibatan dari sekretaris, Kasubag Keuangan, Kasubag Perencanaan/Program, tidak mempengaruhi Kinerja Manajerial.

3. Job Relevant information penyusunan anggaran $\left(\mathrm{X}_{3}\right)$ secara parsial tidak berpengaruh terhadap Kinerja Manajerial SKPD pada Kabupaten Kepulauan Talaud, Hal ini berarti Job Relevant Information penyusunan anggaran tidak bisa berperan sebagai variabel moderating terhadap partisipasi penyusunan anggaran dengan kinerja manajerial.

4. Kebijakan Penyusunan Anggaran $\left(X_{4}\right)$ secara parsial berpengaruh terhadap kinerja manajerial. Dalam artian bahwa keterlibatan dari sekretaris, kasubag keuangan, kasubag perencanaan/programdiSKPD KabupatenKepulauan Talaud dalam kebijakan penyusunan anggaran mempengaruhi kinerja manajerial.

5. Pelimpahan wewenang penyusunan anggaran $\left(\mathrm{X}_{5}\right)$ secara parsial berpengaruh terhadap kinerja manajerialartinya semakin ada pelimpahan wewenang yang jelas maka semakin tinggi kinerja manajerial.

\section{Saran}

1. Penelitian berikutnya harus mempertimbangkan karakteristik atau variabel lainyang mempengaruhi Kinerja Manajerial daerah misalnya komitmen dan gaya kepemimpinan.

2. Penelitian ini memberikan tambahan informasi untuk penelitian selanjutnya sehingga dapat membantu pengembangan Ilmu Akuntansi khususnya Akuntansi sektor publik.

\section{DAFTAR PUSTAKA}

Anwar Prabu Mangkunegara. 2010.Evaluasi Kinerja SDM. Hal 61-77.

Albertus, Doni Koesuma. 2010. Pendidikan Karakter: Strategi Mendidik Anak di Zaman Global.Jakarta: Grasindo. 
Boediono, G. SB. 2005. Kualitas Laba : Studi Pengaruh Mekanisme Corporate Governance dan Dampak Manajemen Laba dengan Menggunakan Analisis Jalur. Simposium Nasional Akuntansi VIII : 172-194.

Echols, John M, and Hassan Shadyli, 2000,Kamus Inggris-Indonesia, Jakarta: Gramedia Pustaka Utama

Ghozali dan Casstellan. 2002. Statistik Non Parametrik "Tori dan Aplikasi denganProgam SPSS", Badan Penerbit Universitas Diponogoro, Semarang.

I Nyoman Sumaryadi 2010, Efektifitas Implementasi Otonomi Daerah. Jakarta: Citra Utama

Mekson Waney, 2012. Pengaruh partisipasi penyusunan anggaran, kepuasan kerja budaya organisasi terhadap kinerja aparatur SKPD.

Mulyadi. 2001. Akuntansi Manajemen: Konsep, Manfaat, \& Rekayasa. Edisi 3. Yogyakarta: Salemba Empat

Ompusunggu Krisler Bomadi \&Bawono, Icuk Rangga,, (2006).. Pengaruh Partisipasi Anggaran dan Job Relevant Information(JRI) terhadap informai asimetris (studi pada badan layanan umum) universitas di kota Purwokerto jawa tengah

Riant Nugroho D, 2004, Kebijakan Publik: Formulasi, Implementasi dan Evaluasi, Gramedia, Jakarta.

Ridwan HR, Hukum Administrasi Negara. 2006, Jakarta: PT.Raja Grafindo Persada.

Surya, Dharma. 2005. Manajemen Kinerja: Falsafah Teori dan Penerapannya, Cetakan I. Yogyakarta: Pustaka Pelajar.

Yogi Adrianto (2008), Analisis pengaruh partisipasi penyusunan anggaran terhadap kinerja manajerial dengan kepuasan kerja, job relevant information, dan kepuasan kerja sebagai variable intervening.

Yusfaningrum, 2005, Analisis pengaruh partisipasi anggaran terhadap kinerja manajerial melalui komitmen tujuan anggaran dan job relevant information (JRI) sebagai variable intervening. Usahawan ,07 juli hal. 7-13

Depdagri RI. 2007. Permendagri Nomor 30 Tahun 2007 tentang Pedoman Penyusunan Anggaran Pendapatan dan Belanja Daerah Tahun Anggaran 2008.

Depdagri RI. 2006. Permendagri Nomor 13 Tahun 2006 tentang Pedoman Pengelolaan Keuangan Daerah.

Undang-Undang Nomor 23 Tahun 2014 tentang Pemerintahan Daerah

Undang-Undang Nomor 17 Tahun 2003 tentang Keuangan Negara

Undang-Undang Nomor 33 Tahun 2004 tentang Perimbangan Keuangan

http://www.kpu.go.id/dmdocuments/UU Nomor 23 Tahun 2014 Pemerintahan Daerah

http://www.djpk.depkeu.go.id, UU 33 2004,, tentang Perimbangan Keuangan

http://manado.bpk.go.id

http: //www.bpk.go.id, Undang-undang nomor 17 tahun 2003, tentang Keuamgan Negara 